\section{ekf}

VYSOKÁ ŠKOLA BÁŇSKÁ EKONOMICKÁ FAKULTA

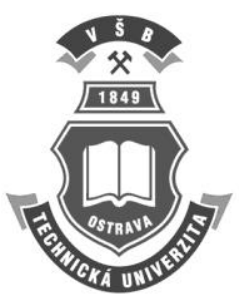

\title{
Multiple-criteria decision making applied in the evaluation of corporate social responsibility using the AHP method
}

\author{
Štěpánka STAŇKOVÁ*
}

Department of Management, Faculty of Economics, VŠB-Technical University of Ostrava, Sokolská třida 33, 70121 Ostrava, Czech Republic.

\begin{abstract}
Together with the managerial decision to run a business in accordance with corporate social responsibility (CSR) principles, important questions dealing with the necessity of systematic CSR evaluation and measurement should be answered. The main goal of this article is connected with a complex assessment of the CSR activities of two selected organizations operating in the Czech food processing market using the analytic hierarchy process method (AHP). The priorities for the criteria and sub-criteria of a hierarchically structured decision-making task are determined by Saaty's pairwise comparison method based on the subjective opinions of an expert. The computed results are described with respect to a distributive mode synthesis and an ideal mode synthesis.
\end{abstract}

\section{Keywords}

Analytic hierarchy process, business ethics, corporate social responsibility, evaluation, multiple-criteria decision making

JEL Classification: M14, L21

\footnotetext{
* stepanka.stankova@vsb.cz

This paper is supported by the Student Grant Competition of the Faculty of Economics, VŠB-Technical University of Ostrava (project registration number: SP2014/126).
} 


\title{
Multiple-criteria decision making applied in the evaluation of corporate social responsibility using the AHP method
}

\author{
Štěpánka STAŇKOVÁ
}

\section{Introduction}

Business activities, trading and permanent competing have become essential components of human society. Shortly after the end of the Second World War, economists from all over the world started to contemplate various economic aspects of how to increase production together with the simultaneous possibility of an improvement of living standards. The idea of maintaining an appropriate economic performance that should be universally beneficial for the whole society was very popular at that time because the impacts of this opinion could positively affect the decreasing level of economic criminality, fraud and discrimination. On the other hand, the portfolio of various products and services could grow together with the minimization of health and safety risks of employees and consumers. The following topics, such as environmental protection, research and development and education, should be considered by every company.

In 1953 the American economist Howard R. Bowen (Putnová and Seknička, 2007) introduced his book entitled Social Responsibilities of the Businessman, which served as a source of inspiration for the name of the special study of corporate social responsibility (in short CSR). Specialized research centres focusing on the exploration and examination of this dynamically developing field have gradually emerged. Moreover, organizations supporting and promoting sustainable and responsible entrepreneurship have been established worldwide. For example, the European Business Ethics Network, International Business Leaders Forum and CSR Europe are among the most popular ones at the global level. The issues of CSR have become important topics of international conferences and discussions.

Generally, the CSR concept can be understood as the voluntary commitment of various organizations to following the principles of responsible behaviour and social engagement. CSR not only should be practised in particular companies but should be applied globally in every business entity participating in production, distribution, marketing, selling and disposal. The broad thematic range of the CSR concept integrating a large quantity of scientific fields and expert opinions leads to a terminological disunity resulting in many various definitions. Considering these circumstances and facts, the exact measurement of CSR activities is a very questionable and difficult task.

The main goal of this paper is connected with the complex evaluation of the CSR approaches of the two leading organizations operating in the Czech food processing market using the analytic hierarchy process method (AHP). For this purpose, Saaty's pairwise comparison method based on the subjective opinion of an expert is used for the mathematical quantification of the relative importance of specified criteria. The computed results are described with respect to a distributive mode synthesis and an ideal mode synthesis.

The theoretic part of this paper is focused on more detailed characteristics of the CSR concept, its basis and the contemporary possibilities of CSR measurement tools. The application of the AHP method is minutely described in the methodological section, followed by the practical part containing a brief introduction to the CSR strategies used in the chosen organizations. Finally, the obtained results and the other methods that could possibly be used in this research are discussed and summarized.

\section{Theoretical background of corporate social responsibility}

In connection with the development of various definitions and characteristics of the CSR concept, it is necessary to mention the two most elaborated and quoted theories that, in fact, polarize the opinions on these issues. The stockholder theory states that there is only one social responsibility: to use resources to support profit-maximizing business activities but without breaking the law or committing deceptions or fraud. On the other hand, every business organization should respect the ethical conventions and encourage beneficial social results. This theory was introduced by Milton Friedman in 1970 (Putnová and Seknička, 2007) and represents a narrow conception of CSR that focuses on owners as investors who carry the risk of a 
lack of success. Owners are the ones who make the key decisions but they also have to entrust their managers with the power to support profit maximization (Bláha, 2001; Horrigan, 2010).

In 1984 Richard Edward Freeman presented the stakeholder theory as his critical reaction to Friedman's work. It claims that the diverse interests of all stakeholders - employees, suppliers, customers, trade unions, local communities, NGOs, financial institutions, etc. - should be taken into consideration as well. The stakeholders could include individuals or they could form groups that are positively or negatively influenced by the business activities. The stakeholders, however, could similarly affect the organizations and their goals (Putnová and Seknička, 2007). This mutual dependence, following the stakeholder theory, is evident for example in the Green Paper by the Commission of European Communities (2001) describing CSR as a concept whereby companies integrate social and environmental concerns into their business operations and into their interaction with their stakeholders on a voluntary basis.

Kunz (2012) pointed out that what the CSR definitions have in common are a long-term orientation, a systematic character and voluntariness together with unlimited possibilities for practical application. Dytrt et al. (2006) dealt with the CSR concept as an innovative activity forming a vital part of an organizational strategy and its development, reflecting the appropriate managerial style. Authors such as Bartošová (2006b), Coombs and Holladay (2012), Horrigan (2010) and Pavlík and Bělčík (2010) were familiar with the triple-bottom-line approach also presented by the European Union, which includes three basic areas of interest: Profit, Planet and People.

- Profit: A responsible organization conducts business transparently, respects corporate governance rules, ethical marketing policies and ethical codes, pays attention to quality, innovations or safety and is universally beneficial to its community. Corporate donations or employee volunteering programmes are supported as well.

- Planet: An environmentally sustainable organization uses environment-friendly technologies, supports their development and reduces its environmental impacts.

- People: A responsible organization also fully respects human rights and occupational health standards and is fair in relation to its stakeholders. Principles of diversity management focusing mainly on women, handicapped people, ethnic minorities and seniors together with the rules of work-life balance are taken for granted. An organization looks after dismissed em- ployees to find a new job. Various retraining courses or career consultancy possibilities are provided for free.

\section{Current methods of measurement and evalua- tion of CSR activities}

The level of a systematic assessment of CSR activities in organizations is dependent on the individual understanding of the CSR principles by owners, managers and employees, together with their internal explanations of the necessity of permanent implementation, monitoring and regular evaluation of this abovestandard commitment. Publicly presented CSR results could be considered as an opportunity to gain a competitive advantage; however, especially small organizations operating regionally take the responsible conduct of business for granted. There are several possibilities to evaluate CSR activities: a special audit carried out by unbiased professionals, certification or a quality mark. All these tools used for the measurement of corporate social responsibility performance differ in their methodologies, complexity and range of suitable applications in various business sectors or organization structures.

A special category connected with the CSR evaluation methodology is represented by the International Standard for Measuring Corporate Community Investment developed by experts from the London Benchmarking Group. It introduces a complex method appropriate for a systematic assessment of corporate community investment effectiveness based on exact cost specifications. The first group deals with corporate donations, the second one concentrates on socially oriented investment in different areas, positively influencing the organizational image, and the third group focuses on social marketing activities (Bartošová, 2006a).

Nowadays, socially responsible investing is considered to be an emerging trend, represented by diverse sustainability indices. Their main deficiency is connected with the fact that only the world's largest companies with stocks that are marketable in global stock markets are tracked. Methodological procedures are based mainly on a weighting process of monitored performance for specified criteria and statistics but every organization has its own requirements. For example, the Dow Jones Sustainability Indices automatically exclude companies interested in the production of alcohol, tobacco, gambling, armaments, landmines, firearms and adult entertainment from their computations (S\&P Dow Jones Indices, 2014).

A separate category of evaluation tools is represented by non-financial reporting initiatives based on the regular publication of CSR reports that could be 
used as a communication medium informing about the CSR progress as well as a complex managerial instrument providing a survey of CSR results. The credibility of CSR reports should be increased by auditor checking (for detailed information see Pavlík and Bělčík, 2010; White, 2009). Regardless of the legal form of the organizations, it is possible to apply content analysis to evaluate or mutually compare the CSR activities mentioned in CSR reports, on Internet pages and in presentations. Practical examples of CSR evaluation possibilities and tools are given in Table 1 .

\section{Analytic hierarchy process}

The AHP method was first introduced by its author Thomas L. Saaty at the beginning of the 1970s. This method has been presented as an efficient and useful tool for multiple-criteria decision making, overcoming the obstacles of intuitive decisions. The AHP is based on the innate human ability to use information and experience during various decision-making processes that also participate in the systematic decomposition of a chosen problem into its smaller constituent parts, forming a hierarchical structure. The first level of a hierarchy is usually represented by a clear specification of decision-making goals or tasks. The second level is connected with the formulation of criteria influencing the final decision, while the third layer includes sub-criteria giving accuracy to every criterion belonging to the previous level. Finally, the fourth level symbolizes a list of considered options concerning which decision-making processes will be realized (Saaty, 2000). In the field of CSR, the AHP could be used in decision-making processes, resulting in the selection of the optimal reaction or behavioural pattern (for examples see Drieniková et al., 2011). On the other hand, the AHP could participate in the evaluation of the CSR activities (see Freitas and Magrini, 2013). Chen and Fan (2011) and Govindan et al. (2013) recommended combining the MADM methods with fuzzy set modelling in order to measure the CSR performance.

First of all, it is necessary to create a hierarchical network with respect to the main goal, which is connected with the evaluation of the CSR activities of two selected organizations operating in the food processing sector. Each criterion is chosen according to the triple-bottom-line definition of CSR (see Chapter 2) while it is specified by three sub-criteria. The graphic representation of the hierarchical structure, together with the indication of criteria and sub-criteria, is provided in Figure 1.

Before beginning the pairwise comparisons, an appropriate number of Saaty's matrices (symbolically marked by $S$ ) have to be prepared. Saaty's matrix has as many rows and columns as there are hierarchical components (criteria, sub-criteria and options). The judgements are written in the matrix according to the estimated importance (preference) of the components.

Table 1 Summary of CSR evaluation tools and methods

\begin{tabular}{|c|c|c|}
\hline Certification/Guidance & Specialization & Organization \\
\hline AA 1000 & $\begin{array}{l}\text { Evaluation of CSR principles' applica- } \\
\text { tion }\end{array}$ & AccountAbility \\
\hline ISO 14001, ISO 14004 & Environmental management system & $\begin{array}{l}\text { International Organization for Stand- } \\
\text { ardization }\end{array}$ \\
\hline ISO 26000 & Guidance on reliable CSR strategies & $\begin{array}{l}\text { International Organization for Stand- } \\
\text { ardization }\end{array}$ \\
\hline Quality Label & $\begin{array}{l}\text { Appraisal of CSR strategy complexity } \\
\text { from stakeholders' point of view }\end{array}$ & Forum Ethibel \\
\hline CSR Evaluation Methodology & Specialization & Organization \\
\hline $\begin{array}{l}\text { International Standard for Measuring } \\
\text { Corporate Community Investment }\end{array}$ & Corporate community investment & London Benchmarking Group \\
\hline Sustainability Indices & Specialization & Organization \\
\hline Ethibel Sustainability Index & \multirow{3}{*}{$\begin{array}{c}\text { CSR performance evaluation of the } \\
\text { world's largest companies with stocks } \\
\text { that are marketable in global stock } \\
\text { markets }\end{array}$} & Forum Ethibel \\
\hline Dow Jones Sustainability Indices & & S\&P Dow Jones Indices \\
\hline FTSE4Good & & London Stock Exchange Group \\
\hline Non-financial Reporting & Specialization & Organization \\
\hline G3. 1 Guidelines & CSR reporting methodology and forms & Global Reporting Initiative \\
\hline
\end{tabular}

Source: own adaptation (AccountAbility, 2013; Bartošová, 2006a; Forum Ethibel, 2013; Global Reporting Initiative, 2013; ISO, 2013; S\&P Dow Jones Indices, 2014; Zadražilová et al., 2010) 


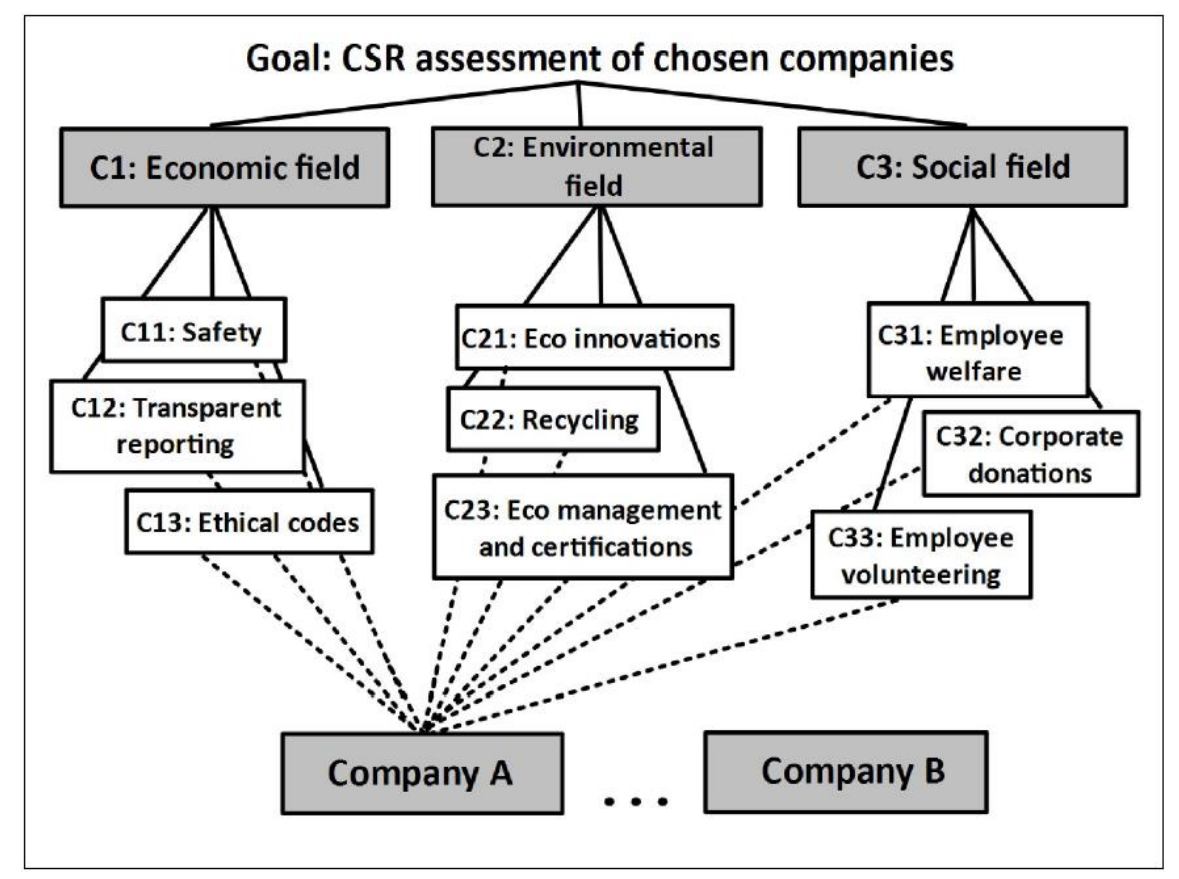

Figure 1 Hierarchical decomposition of decision-making tasks

Source: own adaptation according to the CSR definitions (Bartošová, 2006b; Pavlík and Bělčík, 2010)

When the components in rows are preferred to those in columns, then the numerical expression of magnitudes ranges between $\langle 1 ; 9\rangle$. Value 1 corresponds to equal importance (indifference), number 3 means moderately more, number 5 strongly more, number 7 very strongly more and number 9 extremely more. The values 2, 4, 6 and 8 are used to express a compromise or an intermediate stage of the ratio scale. In the opposite case, the estimated magnitudes are expressed on an inverse scale ranging between $\langle 1 / 2 ; 1 / 9\rangle$. The matrix is reciprocal, which means that its elements, marked $s_{i, j}$, which are symmetric with respect to the diagonal, are inverses of one another, $s_{i, j}=1 / s_{j, i}$. Moreover, the elements on the diagonal express equality and are assigned the value 1 (Saaty, 2000; Zmeškal, 2012).

Once all the paired comparisons on every hierarchical level have been made, the computation of normalized local weights $w_{i}$, representing a contribution to the parent node in the level immediately above, follows. Local weights $w_{i}$ could be calculated for example by using the geometric mean of the rows of Saaty's matrix $S$ according to a mathematic formula:

$$
w_{i}=\frac{v_{i}}{\sum_{i}^{N} v_{i}}=\frac{\left[\Pi_{j}^{N} s_{i, j}\right]^{\frac{1}{N}}}{\sum_{i}^{N}\left[\Pi_{j}^{N} s_{i, j}\right]^{\frac{1}{N}}}
$$

where $N$ represents the order of Saaty's matrix $S$ with elements $s_{i, j}$.

To obtain a high-quality evaluation and reliable results, it is necessary to meet the transitivity condition resulting in the demanded consistency of Saaty's matrices. To assess the consistency, an eigenvalue $\lambda_{\text {max }}$ must be computed with respect to the mathematical procedure given below:

$$
\lambda_{\max }=\frac{1}{N} \sum_{i}^{N}(S \cdot w)_{i} / w_{i},
$$

where $N$ is the order of Saaty's matrix $S, w$ symbolizes an eigenvector of weights $w_{i}$ and $(S \cdot w)_{i}$ stands for the $i$ - th element of vector $w$. The next step is connected with the calculation of the consistency index (CI) according to the following formula:

$$
C I=\frac{\lambda_{\max }-N}{N-1} .
$$

The whole procedure of the consistency evaluation is finished by the computation of the consistency ratio (CR):

$$
C R=\frac{C I}{R I}
$$

while the random index (RI) is determined empirically depending on the order of Saaty's matrix $S$ and the ranging values mentioned in Table 2 . The value of the consistency index must definitely meet the condition $C R \leq 0,1$.

Table 2 Summary of RI values

\begin{tabular}{|c|c|c|c|c|c|c|c|c|c|c|}
\hline $\mathrm{N}$ & 1 & 2 & 3 & 4 & 5 & 6 & 7 & 8 & 9 & 10 \\
\hline $\mathrm{RI}$ & 0.00 & 0.00 & 0.58 & 0.90 & 1.12 & 1.24 & 1.32 & 1.41 & 1.45 & 1.49 \\
\hline
\end{tabular}

Source: Zmeškal (2012) 
To obtain the global importance of each subcriterion considering the overall goal $\left(W_{i j}\right)$, the local weights of criterion $w_{i}$ are multiplied by the local weights of the $j$-th sub-criterion according to its effect on the $i$-th criterion:

$$
W_{i, j}=w_{i} \cdot w_{i, j}
$$

A similar procedure is applied in the final evaluation of the chosen options that are compared with respect to each sub-criterion representing the most detailed level of CSR activities within the hierarchy. After the computation of the global weights of each option and organization, it is necessary to count them separately for each option. The AHP method is based on the principle of utility maximization, which is why the option with the highest sum of the global weights is chosen. This method is called distributive mode synthesis. Another solution to this task could be provided by ideal mode synthesis, which is connected with a relative expression of the global weights, while the ideal value is represented by $100 \%$ (Saaty, 2000).

\section{Brief characteristics of the CSR approach in selected organizations}

The level of CSR activities of the two chosen organizations is appraised by Saaty's paired comparison method. Plzeňský Prazdroj, a.s. is referred to with the expression Organization A and Agrofert Holding, a.s. is Organization B. According to the results of the Czech Top 100 Most Admired Firms survey conducted in 2013, both of these organizations are considered to form an essential part of the Czech food processing sector.

\subsection{Plzeňský Prazdroj, a.s.}

The organization named Plzeňský Prazdroj, a.s. ranks among the leading Czech producers and exporters of beer. It forms part of a global brewery corporation, SABMiller, plc., which promotes and supports an obligatory framework for CSR, sustainable development issues and responsible alcohol consumption, called Ten Priorities. One Future. Since 2006 regular CSR reports have been created and published according to the SABMiller internal methodology. The business activities of Plzeňský Prazdroj, a.s. are transparent, reliable and fully respect the legal regulations, international standards, human rights and several ethical codes. A special ethical commission, ombudsmen and an anti-corruption line help to reveal potential violations and fraud. Responsible behaviour, together with appropriate quality, is demanded from every supplier and properly monitored.

The important part of its CSR strategy is connected with financial support for the regions where its manufacturing facilities are located. The International
Standard for Measuring Corporate Community Investment (LBG) is used for systematic evaluation and comparison. The organization pays attention to environmental innovations dealing with energy and water saving, recycling and waste minimization. The relations between the organization and its employees are based on fair treatment, diversity management practices, equal opportunities and work-life balance principles. Corporate volunteering programmes and payroll giving are widely supported (Plzeňský Prazdroj, 2012).

\subsection{Agrofert Holding, a.s.}

The organization called Agrofert Holding, a.s. offers a broad range of products and services in the food processing industry. The CSR activities and behaviour of the whole Agrofert group are declared by an obligatory ethical code guaranteeing the observance of human rights, anti-discrimination and equal opportunities principles together with occupational safety standards according to the OHSAS norms. Employees can use an anti-corruption line, Tell us, to point out violations and breaking of the ethical rules or law. The organization widely supports environmental protection, recycling and sustainable development. Agrofert Holding, a.s. is a holder of a high-prestige certificate related to fraud and corruption resistance issued by Det Norske Veritas. Since 2011 various philanthropic activities covering cultural, educational, charitable and environmental spheres have been accomplished by a foundation named Nadace Agrofert. The CSR activities and results are not publicly reported (Agrofert Holding, 2013).

\section{Results}

The global weights $\left(W_{i, j}\right)$ are considered to be the most important result, reflecting the relative participation of each sub-criterion in the overall goal, which is afterwards used for a detailed organization comparison and CSR evaluation. The preferences of the criteria and the sub-criteria included in that multiple-criteria decision making are assigned subjectively according to the opinions of one expert. A summary of the computed local and global weights is given in Table 3. In view of the fact that the selected organizations represent the Czech food processing sector, the environmental field $(\mathrm{C} 2)$ is rated as the most preferred criterion. Its local weights $w_{i}$ have a relative value of $56 \%$. The economic field (C1) follows with $32 \%$ and finally the social criterion (C3) with nearly $12 \%$ is the least preferred one. It is obvious that this division of preferences affects the values of the global weights $W_{i, j}$.

The environmental sub-criterion $\mathrm{C} 21$, dealing with various ecological innovations of materials, proce- 
dures and technologies together with changes in behavioural stereotypes, plays the key role because its global weights $W_{i, j}$ have a relative value of $30.13 \%$. The next most important sub-criteria deal with the topics of overall safe organization working $(\mathrm{C} 11$; $19.98 \%)$ and recycling $(\mathrm{C} 22 ; 16.58 \%)$. The less preferred factors are connected with ethical codes (C13), corporate philanthropic activities together with donations (C32) and employee volunteering programmes (C33).

The CSR performance of each food processing organization was considered according to information obtained from a content analysis of current Internet presentations, CSR reports and other available publications and surveys. The final results required for the complex evaluation of the CSR approach of the selected firms were obtained by using distributive mode synthesis based on calculations of the global weights reflecting the organization scores for each sub-criterion. A detailed overview of the local and global weights is provided in Table 4. Plzeňský
Prazdroj, a.s. (Organization A) is considered to be the more successful company from the sample because it has achieved approximately $75 \%$, while Agrofert Holding, a.s. (Organization B) has accomplished nearly $25 \%$.

It is possible to carry out the CSR evaluation according to ideal mode synthesis based on the determination of the maximum values within the organizations' global weights. Ideal scores represent $100 \%$ and the remaining values are expressed as a relative part of each ideal. The results of this procedure, which serves as another method of interpretation, are shown in Table 5. In all the economic and environmental criteria and two social sub-criteria, Plzeňský Prazdroj, a.s. (Organization A) is considered to be the ideal. Agrofert Holding, a.s. (Organization B; approx. 33\%) achieves the best value in corporate donations (C32), which certainly affects the total score of the organization A $(98 \%)$. For a graphic overview of the global weights computed using both syntheses, see Figure 2 and Figure 3 in the Appendices.

Table 3 Overview of local and global weights

\begin{tabular}{|c|c|c|c|c|c|c|c|c|c|c|}
\hline Criterion & \multicolumn{3}{|c|}{$C 1$} & \multicolumn{3}{|c|}{$C 2$} & \multicolumn{3}{|c|}{$C 3$} & Sum \\
\hline Local $w_{i}$ & \multicolumn{3}{|c|}{0.3196} & \multicolumn{3}{|c|}{0.5584} & \multicolumn{3}{|c|}{0.1220} & 1.0000 \\
\hline Sub-criterion & $C 11$ & $C 12$ & $C 13$ & $C 21$ & $C 22$ & $C 23$ & C31 & $C 32$ & C33 & \\
\hline Local $w_{i, j}$ & 0.6250 & 0.2385 & 0.1365 & 0.5396 & 0.2970 & 0.1634 & 0.6738 & 0.2255 & 0.1007 & \\
\hline Global $W_{i, j}$ & 0.1998 & 0.0762 & 0.0436 & 0.3013 & 0.1658 & 0.0913 & 0.0822 & 0.0275 & 0.0123 & 1.0000 \\
\hline$\%$ & $19.98 \%$ & $7.62 \%$ & $4.36 \%$ & $30.13 \%$ & $16.58 \%$ & $9.13 \%$ & $8.22 \%$ & $2.75 \%$ & $1.23 \%$ & $100.00 \%$ \\
\hline
\end{tabular}

Table 4 Results of the distributive mode synthesis

\begin{tabular}{|l|c|c|c|c|c|c|c|c|c|c|}
\hline Sub-criterion & $C 11$ & $C 12$ & $C 13$ & $C 21$ & $C 22$ & $C 23$ & $C 31$ & $C 32$ & $C 33$ & Sum \\
\hline Global $W_{i, j}$ & 0.1998 & 0.0762 & 0.0436 & 0.3013 & 0.1658 & 0.0913 & 0.0822 & 0.0275 & 0.0123 & \\
\hline A - local $w$ & 0.6667 & 0.8333 & 0.7500 & 0.8000 & 0.8333 & 0.6667 & 0.8333 & 0.1429 & 0.6667 & \\
\hline A-global $w$ & 0.1332 & 0.0635 & 0.0327 & 0.2411 & 0.1382 & 0.0608 & 0.0685 & 0.0039 & 0.0082 & 0.7501 \\
\hline B - local $w$ & 0.3333 & 0.1667 & 0.2500 & 0.2000 & 0.1667 & 0.3333 & 0.1667 & 0.8571 & 0.3333 & \\
\hline B-global $w$ & 0.0666 & 0.0127 & 0.0109 & 0.0603 & 0.0276 & 0.0304 & 0.0137 & 0.0236 & 0.0041 & 0.2499 \\
\hline
\end{tabular}

Table 5 Results of the ideal mode synthesis

\begin{tabular}{|l|c|c|c|c|c|c|c|c|c|c|}
\hline Sub-criterion & $C 11$ & $C 12$ & $C 13$ & $C 21$ & $C 22$ & $C 23$ & $C 31$ & $C 32$ & $C 33$ & Sum \\
\hline Global $W_{i, j}$ & 0.1998 & 0.0762 & 0.0436 & 0.3013 & 0.1658 & 0.0913 & 0.0822 & 0.0275 & 0.0123 & 1.0000 \\
\hline A & 1.0000 & 1.0000 & 1.0000 & 1.0000 & 1.0000 & 1.0000 & 1.0000 & 0.1667 & 1.0000 & \\
\hline A recount & 0.1998 & 0.0762 & 0.0436 & 0.3013 & 0.1658 & 0.0913 & 0.0822 & 0.0046 & 0.0123 & 0.9771 \\
\hline B & 0.5000 & 0.2000 & 0.3333 & 0.2500 & 0.2000 & 0.5000 & 0.2000 & 1.0000 & 0.5000 & \\
\hline B recount & 0.0999 & 0.0152 & 0.0145 & 0.0753 & 0.0332 & 0.0456 & 0.0164 & 0.0275 & 0.0061 & 0.3339 \\
\hline
\end{tabular}




\section{Conclusion}

The main goal of this paper is connected with the evaluation of CSR activities in two selected food processing organizations using the AHP method. Due to the spontaneous and unlimited evolution of CSR definitions and characteristics, the exact measurement of CSR performance is a questionable task. Nowadays, various methods, such as external audits, certifications, quality marks, sustainability indices or nonfinancial reporting initiatives, can be appropriately used for a systematic CSR assessment, but they differ in complexity and methodology and they are focused on specific areas in which special requirements have to be met. A solution of multiple-criteria decisionmaking tasks based on hierarchical decomposition and paired comparisons should be helpful and provide reliable sources for suitable CSR evaluation procedures.

The application of the AHP method in CSR evaluation topics has been demonstrated on a sample consisting of the two organizations Plzeňský Prazdroj, a.s. (Organization A) and Agrofert Holding, a.s. (Organization B). According to the results of the Czech Top 100 Most Admired Firms survey conducted in 2013, both organizations are considered to be an essential part of the Czech food processing sector. The preferences of the criteria and the sub-criteria included in the multiple-criteria decision-making task were assigned subjectively and had an impact on the values of the local and global weights. The environmental field, followed by the economic and social spheres, was the most appraised criterion in that case.

The CSR performance of each chosen organization was considered according to information obtained from a content analysis of current Internet presentations, CSR reports and other available publications and surveys. Both syntheses produced the same ranking of organizations within the sample. As emerged from the distributive mode synthesis, Plzeňský Prazdroj, a.s., representing a firm promoting a successful CSR approach, achieved the best result (75\%), while Agrofert Holding, a.s. scored nearly $25 \%$. According to the ideal mode synthesis, Plzeňský Prazdroj, a.s. is considered to be the ideal in all the economic and environmental criteria and two of the social sub-criteria, which resulted in $98 \%$. Agrofert Holding, a.s. achieved the best value only in the criterion dealing with corporate donations and its CSR performance was quantified as nearly $33 \%$. These results should also be used appropriately for the subsequent determination of strengths and weaknesses of each CSR strategy or CSR benchmarking procedures.
It is assumed that the obtained results related to the preferences' distribution among the criteria and subcriteria will be applicable to similar organizations operating in the Czech food processing sector. By contrast, the preferred criteria and sub-criteria will be different for other business sectors (e.g. banking or educational organizations would probably give greater preference to economic or social fields). For a further analysis, it is recommended to explore the differences between business sectors in the Czech Republic and those in other countries.

On the other hand, the AHP method is connected with a restraint based on the limited number of included options, which results in a significant difficulty of paired comparisons. That is why only a limited amount of organizations can be compared and evaluated. In addition, the fact that the final results and determined ideal values are dependent on the choice of organizations included in the sample has to be taken into consideration during the interpretation of the results. The subjectivity of preferences' distribution could be overcome by expert opinions and group decision-making methods (for further information, see Saaty, 2000). In the CSR evaluation field, data envelopment analysis (DEA) or the decision-making trial and evaluation laboratory (DEMATEL) and analytic network process (ANP) working with dependencies and feedback among all the elements involved in a decision could be used to undertake various decisionmaking tasks as well.

\section{Acknowledgements}

This paper is supported by the Student Grant Competition of the Faculty of Economics, VŠB-Technical University of Ostrava; the project's registration number is SP2014/126. All support is greatly acknowledged and appreciated.

\section{References}

BARTOŠOVÁ. Z. (2006a). Průvodce firemní filantropií. Praha: Fórum dárců.

BARTOŠOVÁ. Z. (2006b). Měrení a benchmarking jako součást strategie CSR. Praha: Fórum dárců.

BLÁHA. J. (2001). Podnikatelská etika - předpoklad úspěšného rozvoje organizace. Ostrava: VŠB-TUO.

CHEN. S., FAN. J. (2011). Measuring corporate social responsibility based on a fuzzy analytical hierarchy process. International Journal of Computer Network and Information Security 3(5): 13-22. http://dx.doi.org/10.5815/ijcnis.2011.05.02

COOMBS. W. T., HOLLADAY. S. J. (2012). Managing Corporate Social Responsibility: Communication Approach. Chichester: Wiley - Blackwell. 
DYTRT. Z. et al. (2006). Etika v podnikatelském prostředí. Praha: Grada.

FREITAS. A., MAGRINI. A. (2013). Multi-criteria decision-making to support sustainable water management in a mining complex in Brazil. Journal of Cleaner Production 47: 118-128.

http://dx.doi.org/10.1016/j.jclepro.2012.10.043

GOVINDAN. K., KHODAVERDI. R., JAFARIAN, A. (2013). A fuzzy multi-criteria approach for measuring sustainability performance of a supplier based on triple bottom line approach. Journal of Cleaner Production 47: 345-354.

http://dx.doi.org/10.1016/j.jclepro.2012.04.014

HORRIGAN. B. (2010). Corporate Social Responsibility in the 21st Century. Massachusetts: Edward Elgar Publishing.

KUNZ. V. (2012). Společenská odpovědnost firem. Praha: Grada.

PAVLÍK. M., BĚLČÍK. M. (2010). Společenská odpovédnost organizace - CSR v praxi a jak s ním dál. Praha: Grada.

PUTNOVÁ. A., SEKNIČKA. P. (2007). Etické ř́zení ve firmè. Praha: Grada.

SAATY. T. L. (2000). Fundamentals of Decision Making and Priority Theory with the Analytic Hierarchy Process. Pittsburgh: RWS Publications.

WHITE. G. B. (2009). Sustainability Reporting: Managing for Wealth and Corporate Health. New York: Business Expert Press.

ZADRAŽILOVÁ. D. et al. (2010). Společenská odpovédnost podniků - Transparentnost a etika podnikání. Praha: C. H. Beck.

ZMEŠKAL. Z. (2012). Aplikace dekompozičních vícekriteriálních metod AHP a ANP ve finančním rozhodování. In: Řizeni a modelováni finančních rizik: sborník prìspěvki̊ z 6. mezinárodni vědecké konference. Ostrava: VŠB-TUO, 689-699.

\section{Additional sources}

ACCOUNTABILITY (2013). AA1000 AccountAbility Principles Standard 2008 [online], cit. 12. 9. 2013. Available from www: <http://www.accountability.org/ images/content/0/7/074/AA1000APS\%202008.pdf>.

AGROFERT HOLDING (2013). Certifikace odolnosti firmy proti korupci. [online], cit. 22. 9. 2013. Available from www: <http://www.agrofert.cz/?1461/protikorupci>.

COMMISSION OF EUROPEAN COMMUNITIES (2001). Green Paper - Promoting a European Framework for Corporate Social Responsibility - released on 18. 7. 2001. [online], cit. 12. 11. 2013. Avail- able from www: <http://www.csr-in-commerce.eu/ data/files/resources/717/com_2001_0366_en.pdf>.

DRIENIKOVÁ. K. et al. (2011). Case Studies of Using the Analytic Hierarchy Process Method in Corporate Social Responsibility and Environmental Risk Management. [online], cit. 18. 10. 2013. Available from www: <http://www.mtf.stuba.sk/docs/ internetovy_casopis/2011/1/PDF/drienikova_hrdinova _nano_sakal.pdf>.

FORUM ETHIBEL (2013). Ethibel Sustainability Index. [online], cit. 12. 9. 2013. Available from www: <http://forumethibel.org/content/ethibel_sustainability _index.html>.

GLOBAL REPORTING INITIATIVE (2013). GRI Content Index and Checklists. [online], cit. 11. 9. 2013. Available from www: <https://www.global reporting.org/reporting/reporting-support/reportingresources/content-index-and-checklist/Pages/default. aspx $>$.

ISO (2013). ISO 26000 - Social Responsibility. [online], cit. 17. 10. 2013. Available from www: <http://www.iso.org/iso/home/standards/iso26000.htm $>$.

PLZEŇSKÝ PRAZDROJ (2012). Zpráva o trvale udržitelném rozvoji 2012. [online], cit. 2. 9. 2013. Available from www: <http://www.prazdroj.cz/data/ web/spolecenska-odpovednost-2012/>.

S\&P Dow Jones Indices (2014). Dow Jones Sustainability World Index Methtodology. [online], cit. 5.11.2014. Available from www: <http://eu.spindices. com/indices/equity/dow-jones-sustainability-worldindex>. 


\section{Appendices}

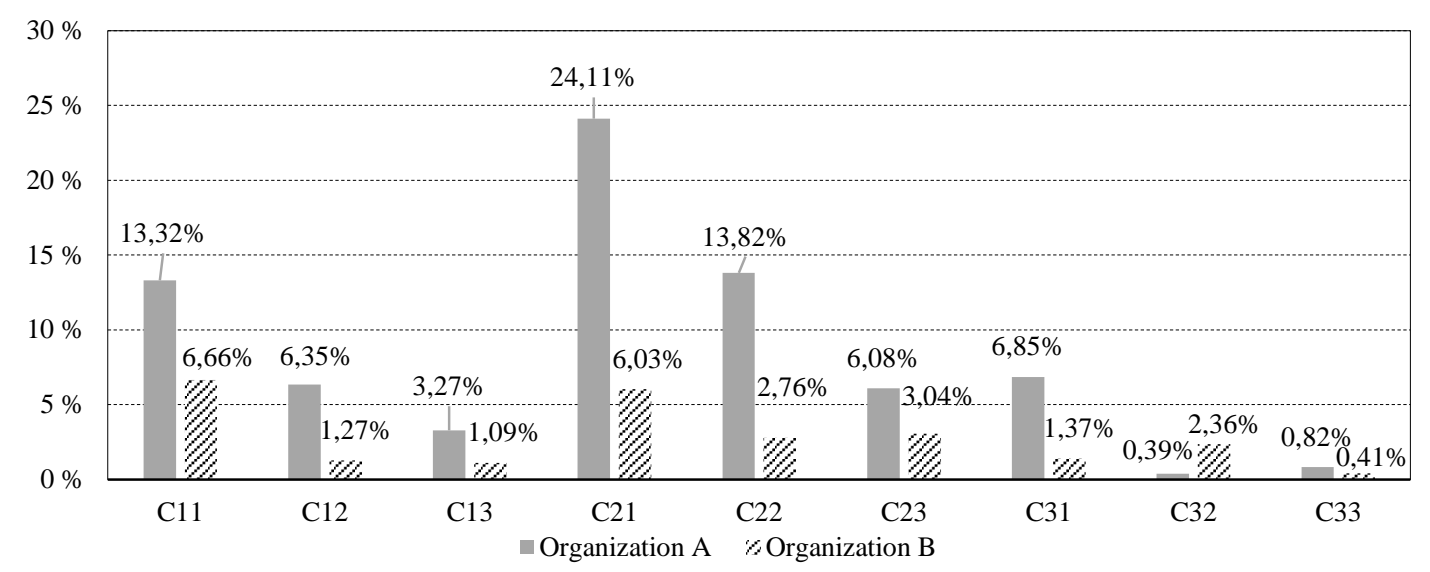

Figure 2 Graphic overview of organization global weights computed according to the distributive mode synthesis

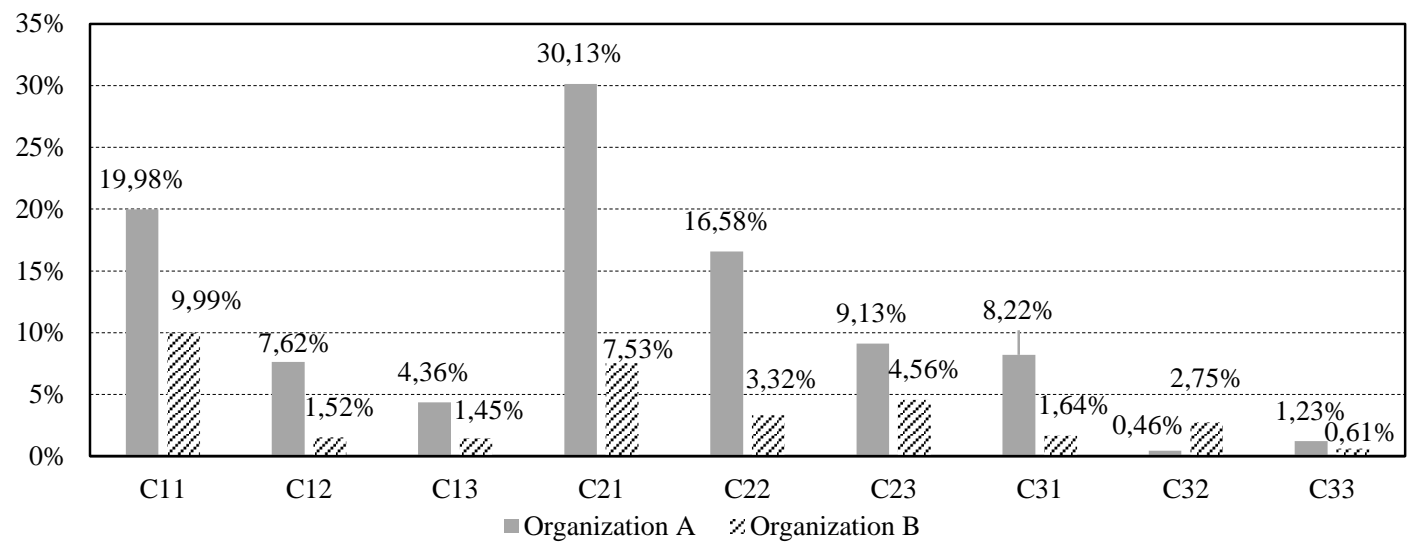

Figure 3 Graphic overview of organization global weights computed according to the ideal mode synthesis 